\title{
Study on the Financing Mechanism and Management Problem in Domestic Private Colleges
}

\author{
Shuaihong Wang \\ Xi'an International University, Xi'an, Shaanxi, 710077
}

Keywords: Financing Mechanism, Management Problem, Private Colleges

\begin{abstract}
With the rapid development of Chinese higher education, Chinese private institutions of higher learning are also taking the wind and waves, rapid development, development has become an important part of Chinese higher education. But in its development process, some problems become increasingly prominent. Which is particularly serious problem, has become a major obstacle to the development of private colleges and universities in China. In recent years, the state has introduced a series of policies to support the development of private education, but some policies also need to further refine the refinement, and there are still many to be added to improve.
\end{abstract}

\section{Introduction}

Chinese private higher education has become an important part of Chinese higher education, its development has a certain scale, and achieved amazing results, the level of continuous improvement, rich disciplines, talent training model flexible. However, in the development of private higher education in China at the same time, also accompanied by some contradictions and problems, and may become the development of its steep stone, the most serious of which is a financial problem. Narrow source of funds, a single financing, there has been financing difficulties. On the other hand, some private colleges and universities in the lack of scientific and scientific decision-making system, or conservative management, or blind expansion, so insolvent, the school stretches difficult, funding problems become overwhelming private institutions of higher learning A straw, has become a fundamental problem affecting the development of private colleges and universities. Private colleges and universities funding a single source, too much dependence on tuition fees, school development has been seriously hampered. Therefore, private colleges and universities in order to long-term sustainable development, we must improve the financing methods and channels, open the "financial way", multi-channel financing.

At present, there are many researches on the financing mechanism of private colleges and universities, and the results of foreign scholars have more research on the financing of private colleges and universities. To solve the problem of financing private universities in our country, it is obviously not necessary to copy foreign experience directly. We must find out the financing mechanism and mode with Chinese characteristics suitable for the development of private institutions of higher learning in our country according to our national conditions and form a complete theoretical system, To solve the problem of financing the private institutions of higher learning in China. Therefore, this subject has important theoretical and practical significance for the research of private higher education financing theory.

\section{Analysis of the Current Situation of Financing of Private Colleges}

After the reform and opening up, Chinese private colleges and universities have developed rapidly, but still in the initial stage. In the development process there are some problems that can not be ignored, narrow source of funds, financing a single, there has been financing difficulties. On the other hand, some private colleges and universities in the lack of scientific and scientific decision-making system, or conservative management, or blind expansion, so insolvent, the school stretched difficult, the funding problem became overwhelming private institutions of higher learning A straw, has become a fundamental problem affecting the development of private colleges and universities. Private colleges and universities funding a single source, too much dependence on 
tuition fees, school development has been seriously hampered. With the development of the school, it is difficult to meet the needs of the school's own development. Part of the school capital chain rupture, serious bankruptcy tendency. In addition, the use of funds, many private colleges and universities use of funds is not efficient, so private colleges in order to long-term sustainable development, we must improve the financing methods and channels, open the "money", multi-channel financing.

\section{Financing Mode of Private Colleges}

At present, Chinese private institutions of higher learning financing channels can be divided into two categories. One is private institutions of higher learning internal business activities of the financing, referred to as internal financing. This part of the funds mainly include tuition and fees, school operating income, school research and transformation of part of the income, logistics rental social contract revenue. The other is the external financing of the school funds, is funded by private institutions of higher learning to other economic entities other than the funds raised, including government financial support, commercial bank loans, social donations, corporate investment and other financing models.

Private colleges and universities are private non-enterprise, its nature belongs to the public welfare category, and enterprises for the purpose of profit for different purposes, private institutions of higher learning for Chinese economic construction has cultivated a large number of professionals, reducing the modernization of the demand for talent and professional talent limited The contradiction between the government and the community to benefit from it. The rise and development of private institutions of higher learning has promoted the reform and development of higher education in China to a certain extent. In recent years, the government has also realized that private colleges and universities play an important role in Chinese higher education, more and more attention to the development of private colleges and universities. 2010 Ministry of Education promulgated the "Education Plan" also proposed to vigorously support the development of private higher education, local governments at all levels of the financial sector also take a variety of preferential policies and measures to support private institutions of higher learning, have increased Education budget for private higher education institutions. In 2009, the Ministry of Education budgeted the national private schools within the budget of 72.12 billion yuan, of which private institutions of higher education budget funds only 1.898 billion yuan. The government's support for private institutions of higher learning also has room for improvement. Taking the budgetary funds in 2009 as an example, the budgets of private universities account for only $0.82 \%$ of the national higher education, and there are still many vague areas in some policies. "Reasonable return" and other aspects of the policy in the operation there are still many problems, the implementation process did not clear the standard supervision of gas.

Economic development can not be separated from financing, financing can not do without credit. Today, commercial bank loans have generally become an important way for private institutions of higher learning to raise funds. Private institutions of higher learning in order to further expand the scale of running a school, need a lot of money as a support. Therefore, many private colleges and universities try to form strategic partners with commercial banks, banks provide financial services for schools, therefore, commercial bank loans to become private institutions of higher learning to solve the shortage of funds is an important way out. According to relevant statistics, Chinese private institutions of higher learning in the financing of bank loans accounted for about $5 \%$, due to some policy restrictions, private colleges and universities from the bank loan is still more difficult.

At present, social donations in China mainly come from some loving overseas Chinese, Hong Kong and Macao compatriots and some keen on public welfare enterprises and individuals. Chinese "Private Education Promotion Law" also clearly stipulates that the state encourages and supports donations to school. For the development of private higher education to make outstanding contributions to the cause of the organization and individuals, the state will give some reward and recognition. In Western developed countries, many of the world's leading private universities, a large part of their funding comes from social donations, which have a lot of alumni, social 
enthusiasts and entrepreneurs donated. Many schools have dedicated alumni donations, specifically responsible for managing alumni donation related matters. At present in our country, the social donation in private colleges and universities in the proportion of running money is very small. On the one hand, due to the development of Chinese private institutions of higher learning is still in the ascendant stage, there is no foreign private institutions mature, and social awareness, reputation, influence is not high enough, the community of private colleges and universities there are some prejudices. On the other hand, Chinese relevant policy system is not perfect, corporate charity, social charity and other related preferential policies for enterprises and individuals to stimulate the role is not obvious. With the development of economic and social civilization, more and more international friends and enterprises to donate to our private institutions of higher learning, the relevant state departments are also actively introduced relevant measures to guide the social funds to private institutions of higher learning to contribute.

Enterprises to invest in school, refers to the private colleges and universities by enterprises or enterprise groups directly investment, the required school funding in whole or in part by the enterprise or enterprise groups. Investment enterprises in the provision of funds at the same time, the school can also provide the necessary experimental, internship conditions and to absorb some of the graduates. Because of these conditions, the school's success rate is usually relatively large. At present, there are several groups which are successful in investing in our country's enterprise group: Beijing Geely Group, Ningbo Red Eagle Group, Wanxiang Group and Yantai Nanshan Group. They invested in Beijing Geely University, Ningbo Red Eagle Vocational and Technical College, Vocational and Technical College, Yantai Nanshan University and other universities, and these universities are currently running well, such as Beijing Geely University is currently ranked in the private universities in China is still relatively forward, is a typical example of successful business investment.

\section{Macro Policy Recommendations}

At present, due to the national laws and regulations on the private schools of property rights and the right to operate the issue of uncertainty is not clear, hinder a lot of social funds in a variety of forms into the field of private higher education. Therefore, private institutions of higher learning financing difficulties, in this case only clearly defined private property rights in order to fully mobilize the enthusiasm of internal investors to attract more social forces to support private colleges and universities.

To enhance investor confidence in investment, should be in accordance with relevant standards and requirements, according to the law division of school property rights, so that investors share school income. At present, Chinese private colleges and universities have three kinds of school mode: one is the social donation school, the second is to invest in school, the third is a mixed fund-raising school. Specific property rights and interests are divided into the following types: the first is the organizers of private colleges and universities invested in the investment owned by the organizers; the second is the state of private school assets owned by the state, the right to use the school legal person all?. On the school bankruptcy liquidation of the remaining property ownership, according to the different investment subjects to take a different approach. For the return of the main investment, should return the final bankruptcy liquidation of the remaining property, and for a reasonable return on investment in the main body, should return to the original investment for the bankruptcy liquidation of the remaining property should be owned by the state, and continue to use for the development of private Higher education.

In developed countries such as the United States and Japan have a sound tax incentives, through the collection of high estate tax and donation tax relief system to guide and encourage social donations. China should also learn from such experience, and actively set up tax incentives, donations to the enterprise, tax relief and concessions to encourage social capital into the field of private higher education. Actively introduce a variety of tax incentives and donation incentive system, simplify the donation process, reduce the donor tax, to encourage and guide enterprises and enthusiasts to donate and donate in the community to create a warm atmosphere and atmosphere, 
develop and nurture potential donation market, For the development of Chinese private higher education to open up a bright path.

In our country try to establish a private education guarantee system, is conducive to private colleges and universities financing, private colleges and universities is an important guarantee for sustained and healthy development. Chinese government can learn from foreign experience for private colleges and universities to set up a special guarantee institutions or guarantee funds, so as to open a door for private university loan investment, financing for private colleges is a new initiative. The private education guarantee fund can be set up by the government financial appropriation, enterprise social donation, etc., for the funds donated to the fund can give tax incentives. And ultimately the formation of government-led, business participation, banks and other financial institutions to establish an education guarantee system for the financing of private education to facilitate the private colleges and universities is conducive to out of financial difficulties, is conducive to sustainable development of private colleges and universities, is conducive to the country The healthy development of private education.

\section{Conclusion}

Private colleges and universities, governments and society should pay attention to these problems and analyze the causes of positive research countermeasures, explore new financing mechanism, truly diversified financing, in order to allow private higher education to continue to develop healthably, for our education industry continue to build blocks.

\section{Acknowledgements}

2016 Xi'an social science planning fund project: Chinese private higher education public welfare and social development path

No.16IN03

Education Department base project in Shaanxi: Shaanxi private colleges and universities investment and financing management mechanism design and education foundation creation

No. $13 \mathrm{JZ} 074$

\section{References}

[1] Wang Huiqing, Liu Xun. Analysis of the development of private colleges and universities financial management [J]. Contemporary economy, 2007 (01)

[2] He Wenbiao. From the institutions to non-profit organizations - Chinese university financial accounting reform [J]. Journal of Southwest Jiaotong University, 2005 (03)

[3] Yang Xiaodan. Private Higher Education Cost Analysis and Revelation [J]. Journal of East China Jiaotong University, 2005 (03)

[4] Liu Lanping. Private Higher Education Cost Sharing the main comparative study [J]. Higher Education Exploration, 2005 (01)

[5] Que Haibao, Du Wei, Huang Yuxiang. Private Higher Education funding analysis [J]. Jiangsu Higher Education, 2004 (06)

[6] Jin Yanlong. Private colleges and universities running the status quo and countermeasures [J]. Economist, 2004 (04) 